\title{
BANANA CULTIVAR DISTRIBUTION IN RWANDA
}

\author{
A. NSABIMANA, S. V. GAIDASHOVA ${ }^{1}$, G. NANTALE ${ }^{2}$, D. KARAMURA ${ }^{3}$ and J. VAN STADEN \\ Research Centre for Plant Growth and Development, School of Biological and Conservation Sciences, \\ University of KwaZulu-Natal, Pietermaritzburg, Private Bag X01, Scottsville 3209, South Africa \\ ${ }^{1}$ Institut des Sciences Agronomiques du Rwanda (ISAR), B.P. 59, Ngoma, Rwanda \\ ${ }^{2}$ Makerere University, P. O. Box 7062, Kampala, Uganda \\ ${ }^{3}$ Bioversity International, P.O. Box 7065, Kampala, Uganda
}

\begin{abstract}
Rwanda is part of the East African plateau where banana (Musa spp.) reach their greatest importance as a staple food crop, covering $23 \%$ of land and grown by $90 \%$ of households. The region is considered a secondary centre of diversity for banana and many cultivars do exist although limited information is available on the diversity and their distribution in the country. In the past, banana have been a highly sustainable crop in Rwanda, but with the introduction of various diseases and pests in the last 10 -20 years, production has fallen by over $40 \%$. The objectives of this study were to (i) establish the current diversity and distribution of banana cultivars, (ii) understand factors that affect the distribution, and (iii) identify possible synonyms and material for expansion of the National Banana Germplasm Collection. A study was conducted in four major banana growing regions of Rwanda. Twelve sites and sixty farms were used in this study. A quadrat method was used to make observations and counts of cultivars grown per farm. Farmer interviews were carried out on each farm to make assessments on the distribution of cultivars. Cultivar identification was done by farmers and subsequently verified using the national banana germplasm collection database of the ISAR-Rubona Research Institute. Clone set identification was done using the Karamura classification system. The Kigali region had the highest diversity index, followed by Kibungo and Cyangugu; while Lake Kivu border region scored the lowest diversity index. Cultivar evenness also differed, with Cyangugu being the highest and Kivu Lake the lowest. There were two major banana subgroups determined at all sites, Lujugira-Mutika with 77.8\% abundance and Pisang Awak with $11.9 \%$ abundance. A total of 104 cultivar names were recorded, with 53 synonyms identified for 51 cultivars. Forty cultivars belonged to Lujugira-Mutika subgroup, with 'Intuntu', 'Intokatoke', 'Injagi', 'Mbwaziruma' being the most abundant cultivars, while eleven cultivars were exotic. Gisubi (ABB), Gros Michel (AAA), and 'Kamaramasenge' (AAB) were the most abundant. Farms with a higher proportion of Gisubi contained fewer other cultivars. Also, new cultivars were identified and these should be added to the National Banana germplasm collection.
\end{abstract}

Key Words: Cultivars, diversity indexes, germplasm, Musa spp.

\section{RÉSUMÉ}

Le Rwanda fait partie du plateau d'Afrique de l'Est où la banana (Musa spp.) atteint leur plus grande importance comme une récolte de nourriture d'agrafe, couvrant $23 \%$ de terre et cultivé par $90 \%$ de ménages. La région est considérée un centre secondaire de diversité pour la banane et beaucoup de variétés existent bien que l'information disponible est limitée sur la diversité et leur distribution dans le pays. Dans le passé, la banane a été une récolte extrêmement viable au Rwanda, mais avec l'introduction de diverses maladies et de diverses pestes dans le dernier 10 -20 ans, la production est tombée à plus de 40\%. Les objectifs de cette étude étaient d’ (i) établir la diversité et la distribution actuelles de cultivars de banane, (ii) comprendre des facteurs qui affectent la distribution, et (iii) identifier des possibles synonymes et le matériel pour l'expansion de la Collection de Germplasm de Banane Nationale. Une étude a été dirigée dans quatre régions majeures du Rwanda qui developpent la culture de bananes. Douze sites et soixante fermes ont été utilisées dans cette étude. Une méthode de quadrat a été utilisée pour faire des observations et des comptes de cultivars grandis par ferme. Les entretiens d'agriculteur 
ont été exécutés sur chaque ferme pour faire des évaluations sur la distribution de cultivars. L’identification de cultivar a été faite par les agriculteurs et par la suite vérifiée utilisant la base de données de collection de germplasm de banane nationale de l'Institut de Recherche d' ISAR-Rubona. L'identification de série clone a été faite en utilisant le système de classification de Karamura. La région de Kigali a eu le plus haut indice de diversité, suivi par Kibungo et Cyangugu ; pendant que la région de frontière de Kivu de Lac a marqué l’indice de diversité plus bas. La région de Kigali a eu le plus haut indice de diversité, suivi par Kibungo et Cyangugu ; pendant que la région frontalière du Lac Kivu a marqué l’indice de diversité plus bas. L'égalité de cultivar a différé aussi, avec Cyangugu est le plus haut et Lac Kivu le plus bas. Il y avait deux sous-groupe majeur de banane résolu à tous sites, Lujugira-Mutika avec 77,8\% abondance et Pisang Awak avec 11,9\% abondance. Un total de 104 noms de cultivar a été enregistré, avec 53 synonymes identifiés pour 51 cultivars. Quarante cultivars ont appartenu au sous-groupe de Lujugira-Mutika, avec « Intuntu », " Intokatoke », " Injagi », « Mbwaziruma » est les cultivars les plus abondants, pendant que onze cultivars étaient exotiques. Gisubi (ABB), Gros Michel (AAA), et « Kamaramasenge » (AAB) étaient le plus abondant. Les fermes avec une plus haute proportion de Gisubi contenaient de moins autres cultivars. Aussi, les nouveaux cultivars ont été identifiés et ceux-ci devraient être ajoutés à la collection de germplasm de Banane Nationale.

Mots Clés: $\quad$ Les varietes, les indices de diversité, germplasm, Musa spp.

\section{INTRODUCTION}

Banana is an important food and cash crop in Rwanda, covering $23 \%$ of the total cultivated land (Mpysi et al., 2000) and is grown by $90 \%$ of households (Lassoudière, 1989). Its production has expanded to marginal areas at altitudes up to 2,200 meters (Charlery de la Masselière, 1989). The history of Rwanda indicates that bananas were introduced in the time of governance of the $11^{\text {th }}$ King of Rwanda, Mibambwe I (1411-1444), with the second invasion of the Abanyoro (Kagame, 1972). During the invasion, the Abanyoro planted bananas in their settlements from where they spread in Rwanda to the rest of the country.

Banana cultivars in Rwanda exist under local names and often within limited distribution. However, due to land pressure, pests, diseases and plant nutritional problems, certain banana cultivars have become rare or completely disappeared (Okech et al., 2002; 2005), while some new varieties were introduced, and others have evolved as mutants from within the existing cultivars. Unfortunately, limited information is available for comparison with the current distribution of cultivars.

The objectives of this study were firstly, to establish the current banana diversity and its distribution in Rwanda; secondly to understand the possible factors affecting banana distribution; and thirdly to work out synonyms and homonyms among cultivars while at the same time identifying new material for expansion of the National banana germplasm collection.

\section{MATERIAL AND METHODS}

The study was conducted during June 2001 at 12 sites covering twelve districts and representing four major banana growing regions in Rwanda (Fig. 1). The four regions covered the exprovinces of Cyangugu, Kibungo, Kigali Rural and Kivu Lake border, including part of Gisenyi and Kibuye provinces. The selection of the sites depended on areas with old banana based cropping systems representative of local banana production farms with more than eight genotypes and at least 120 stools to provide an adequate sample size.

Data were collected based on the agro ecological conditions and altitude of the sites, location of farms in relation to topography of the area, age and size of banana plantations, genome composition and cultivar diversity, banana variety selection criteria applied by farmers and reasons for cultivar disappearance.

The farms were selected randomly from a sampling frame provided by the extension service, a grid representing Central, North, South, East, and Western corners of the site. The distance between farms ranged from 3 to $7 \mathrm{~km}$. Five farms were surveyed at each of the twelve sites, giving a total of sixty farms. On each farm, a quadrat of 


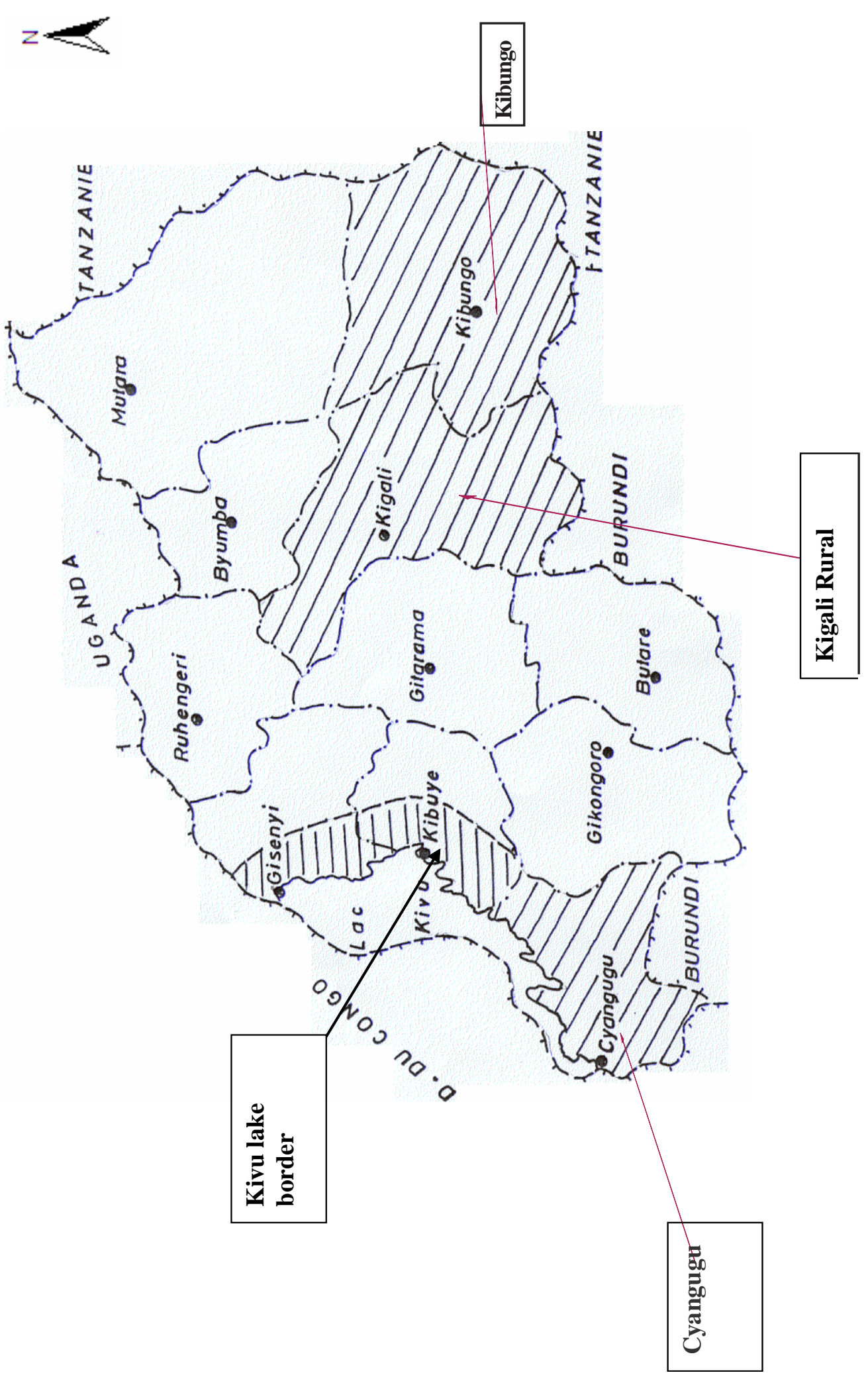

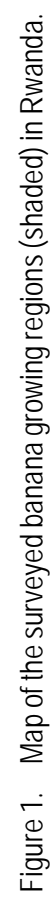


$20 \mathrm{~m}$ x 20 m corresponding to 40-50 banana mats, depending on the density, was used to identify cultivars. The identification was done by farmers and verified using the National Banana Germplasm Collection database from ISARRubona Institute. The Karamura classification system (Karamura and Pickersgill, 1999) was used to group cultivars into clone sets. Preliminary information on synonyms and homonyms found in this survey was reported by Nsabimana (unpublished).

The occurrence of each cultivar, and its use at each farm was determined with the farmers. The distribution of cultivars was estimated as a percentage of farms where a cultivar occurred. Cultivars were grouped into 3 categories: rare (found in less than 5\% of farms), common (5 $34 \%$ farms) and the most common (35\% and more farms). The abundances of individual cultivars, genome groups and end use type were calculated as a percentage of plants of a specific cultivar, genome groups or end use type of total number of banana plants per farm, respectively.

Data recorded from the four regions were used to calculate frequency distributions for cultivars and genome groups, using Microsoft's Excel software. Diversity indexes were calculated using the Shannon-Weaner diversity $(\mathrm{H})$ and evenness (E) indices. SPSS package was to test for significance.

\section{RESULTS}

Data for cultivar richness and evenness are presented in Table 1. Cyangugu region had the largest number of mats on farms, followed by Kigali, Kibungo and Kivu Lake border. As for the overall diversity index, Kibungo and Kigali regions contained the highest number of banana cultivars, while Kivu Lake had the lowest. The overall cultivar evenness was much more in the Cyangugu region (Table 1).

Ten banana sub-groups growing and distributed in the four regions of Rwanda were identified. The most widely distributed banana sub-groups were Lujugira Mutika and Pisang Awak (Table 2). Bluggoe sub-group was very rare. A total of 104 cultivar names were recorded, but there were only fifty one distinct cultivars on the basis of synonyms, from 21,836 total mats identified in the four sites. The number of cultivars identified is shown in Figure 2. Majority of these belonged to Lujugira - Mutika the endemic subgroup in the region, while few were introduced and fewer were considered new cultivars since they were not represented in the banana germplasm collection. The frequency of occurrence of major cultivars is shown in Table

TABLE 2. The abundance of different banana sub-groups in the four study sites

\begin{tabular}{llc}
\hline Group & Subgroup & Abundance (\%) \\
\hline AAA & Lujugira-Mutika & 77.8 \\
& Gros Michel & 1.3 \\
& lbota & 0.7 \\
& Cavendish & 0.6 \\
& & \\
AAB & Silk & 0.2 \\
& Ney Poovan & 5.6 \\
& Prata & 1.7 \\
& Plantain & 0.09 \\
& PBBang Awak & 11.9 \\
& Bluggoe & 0.02 \\
\hline
\end{tabular}

TABLE 1. Cultivar richness and evenness per study site

\begin{tabular}{lccc}
\hline Site & No. of mats & Cultivar richness $(\mathrm{H})$ & Cultivar evenness \\
\hline Cyangugu & 6573 & 0.97 & 0.32 \\
Kibungo & 5668 & 0.98 & 0.28 \\
Kigali & 5700 & 0.99 & 0.29 \\
Kivu lake border & 3895 & 0.68 & 0.22 \\
\hline
\end{tabular}




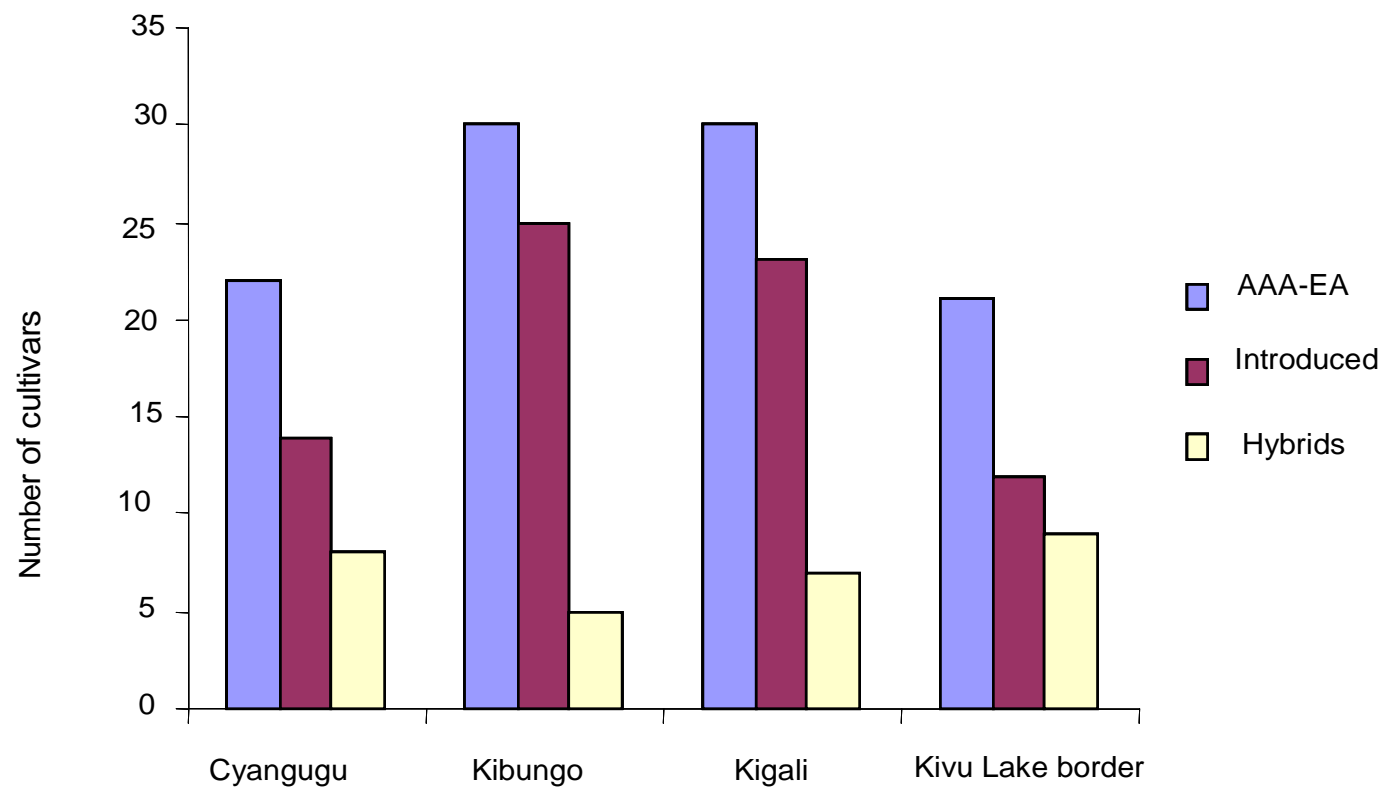

Figure 2. Number of cultivars found in the four surveyed regions of Rwanda.

3. From this study, seven cultivars can be classified as very common, twenty-six as common and eighteen as rare. The rare cultivars constituted more than one third of the total cultivar numbers recorded. Interestingly, farms growing higher proportions of 'Gisubi' variety (Musa ABB) yielded lower numbers $(\mathrm{P}<0.05, \mathrm{r}=$ -0.286).

Banana distribution according to end uses differed across the regions (Fig. 3). Cooking types were dominant in Kibungo and Kigali, with 56.6 and $48.5 \%$, respectively. Brewing types were dominant in Cyangugu and, especially Kivu lake border region with 64.5 and $80.9 \%$ frequency respectively. Dessert bananas were generally less important and had a more uniform distribution across the regions, varying from 6.4 and $6.6 \%$ at Kivu lake border and Cyangugu, to 7.0 and $10.2 \%$ at Kigali and Kibungo, respectively.

\section{DISCUSSION}

This study has confirmed earlier reports that the Lujugira-Mutika sub-group occurs more frequently than other banana sub-groups in Rwanda (Delepierre, 1970; Lassoudière et al., 1989). The study highlighted the distribution and predominance of 'Intuntu' (55\%) and 'Intokatoke' (30\%) cultivars in the four major banana growing regions, confirming their importance in the banana culture of southern Rwanda. (Delepierre, 1970). It would be interesting to study the cultural value of 'Intuntu' and 'Intokatoke' in Rwanda and determine various roles they play in the farming communities of Rwanda. 'Gisubi' is a brewing cultivar, which was introduced in colonial times by INEAC from DR Congo (Delepierre, 1970). It produces a very tasty and strong beer, which quickly provides farmers with income from local markets, hence its importance in the country. Other cultivars like 'Gros Michel', 'Kamaramasenge', 'Injagi', 'Mbwaziruma' and 'Ingenge' are common but not uniformly distributed due to their agronomic requirements. Some of these have specific ecological niche requirements (Ferris et al., 2002). 'Mbwaziruma', for example, prefers monoculture systems. Resulting from the recent spread of fusarium wilt disease, farmers prefer cultivars which are resistant to fusarium wilt such as highland bananas (AAA-EA).

Kibungo and Kigali regions enjoy better market opportunities, creating a high demand for different market oriented cultivars. For Uganda, 
A. NSABIMANA et al.

TABLE 3. Occurrence, abundance and regional distribution of major banana cultivars in four regions of Rwanda

\begin{tabular}{|c|c|c|c|}
\hline Cultivar & Region* & Occurrence ( $\%$ of farms) & Abundance (\% of plants) \\
\hline Barabeshya & 1 & 16.6 & 3.0 \\
\hline Gisubi & $1,2,3,4$ & 60.0 & 11.9 \\
\hline Gisukari & $1,2,4$ & 15.0 & 0.2 \\
\hline Gros Michel & $1,2,3,4$ & 43.3 & 1.3 \\
\hline Ingagara & 2,3 & 15.0 & 0.2 \\
\hline Ingaju brewing & 2,3 & 13.3 & 1.0 \\
\hline Ingaju cooking & 2,3 & 20.0 & 8.4 \\
\hline Ingenge brewing & 2,3 & 5.0 & 0.07 \\
\hline Ingenge cooking & $1,2,3,4$ & 46.7 & 2.6 \\
\hline Ingumba brewing & 2,3 & 30.0 & 0.8 \\
\hline Injagi & $2,3,4$ & 48.3 & 3.6 \\
\hline Intokatoke & $1,2,3,4$ & 55.0 & 15.2 \\
\hline Intuntu & $1,2,3,4$ & 76.7 & 20.8 \\
\hline Intutsi & 2,3 & 26.7 & 9.0 \\
\hline Inyabupfunsi & 1,4 & 16.7 & 0.2 \\
\hline Inzirabahima & $1,2,3,4$ & 31.7 & 1.0 \\
\hline Kamaramasenge & $1,2,3,4$ & 66.7 & 5.6 \\
\hline Madamu & $1,3,4$ & 21.7 & 1.7 \\
\hline Mbwaziruma & $2,3,4$ & 31.7 & 1.5 \\
\hline Mitoki & $1,3,4$ & 18.3 & 3.2 \\
\hline Mutsimawuburo & 2,3 & 26.7 & 0.3 \\
\hline Poyo & $1,3,4$ & 20.0 & 0.6 \\
\hline Umuzibo & 1,4 & 18.3 & 3.6 \\
\hline Yangambi km ${ }^{5}$ & $1,3,4$ & 18.3 & 0.7 \\
\hline
\end{tabular}

*: 1 = Cyangugu; 2 = Kibungo; 3 = Kigali; 4 = Kivu Lake border

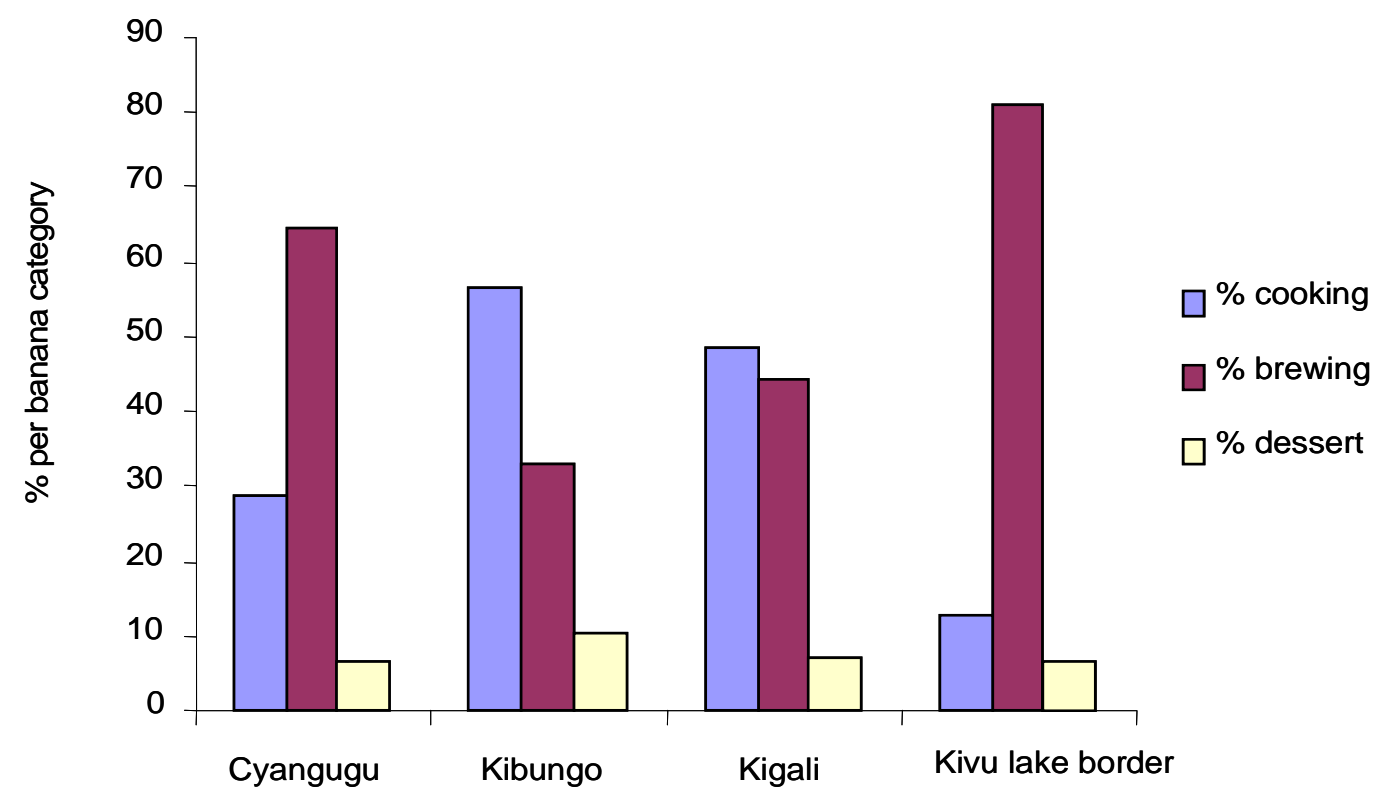

Figure 3. Banana cultivar proportions based on end-use (cooking, brewing and dessert) in four surveyed regions. 
it was reported that areas of high commercial banana production contained fewer cultivars which were more equally (uniformly) distributed (Karamura \& Gauden, pers. comm.). It would be interesting to follow up further how market opportunities may affect banana diversity and distribution in Rwanda. Distributional ranges of cultivars may be due to the value and availability of planting materials of different cultivars, as exemplified by 'Umushaba', a plantain which originated from the Democratic Republic of Congo and is, hence, found only in Cyangugu and North Kivu lake border regions (Gisenyi) which border the DR Congo.

Different genotypes have values and limitations based on their characteristics, and these affect their distributional ranges. For example, 'Ingumba' (brewing type), a variety bearing an empty rachis with no fruits during stress periods, but is otherwise productive, is found at Kibungo on many farms but only in low numbers. Another variety, 'Inkonkobora', a green-cooking type with limited distribution at Kibungo, is known for excessive abscision of fruit at bunch maturity. These rare cultivars should be further developed and given special attention to ensure their conservation and characterisation in the National Banana Germplasm Collection.

The fact that a number of cultivars with the same names exist for brewing and cooking banana (like 'Ingenge', 'Intokatoke', 'Ingaju', 'Icyerwa') may indicate that they originated through mutation of cooking into brewing cultivars or vice versa. Such types of mutation have been mentioned (Jones, 1999). Some authors reported the effect of altitude on the number of banana cultivars at the farm level (Karamura et al., 1996). In this study, altitude did not seem to affect distribution of cultivars across the different regions. Farms with high pre-dominance of 'Gisubi' had a lower number of cultivars. 'Gisubi' tolerates poor soils, multiplies very fast and out competes other cultivars if planted in a mixed cropping system. The fact that it is valued as a beer and market clone, has given it a competitive advantage, increasing in acreage and progressively replacing other cultivars. Since its introduction, 'Gisubi' has spread widely across Rwanda and has replaced highland bananas in regions with poorer soils. Though little research was done on the effect of 'Gisubi' on varieties with low suckering ability, it is obvious that there is a negative correlation between the abundance of 'Gisubi' and number of cultivars per farm. Further research should provide insights in the relationships between different banana varieties within farms and agro-ecologies.

The present study provides data on cultivar group proportions existing in four major banana production regions of Rwanda. It was earlier believed that brewing banana predominates across all regions of the country (Lassoudière, 1986). However, it is now indicated there is a predominance of cooking banana at Kibungo and Kigali. The uniform distribution of dessert bananas is due to better market opportunities in these regions.

\section{ACKNOWLEDGEMENTS}

We acknowledge the contributions of C.M. Gatarayiha, T.K. Mugiraneza, F.X. Karemera B. Uwimpuhwe and T.K. Mugaga for technical assistance in data collection. The Rockefeller foundation funded this research through a grant to IITA. Dr Cliff Gold from CIAT and Dr Suleman Okech from the University of Nairobi are thanked for their advice on survey methodology while working with the IITA team.

\section{REFERENCES}

Charlery de la Masselière, B. 1989. Systèmes de cultures et surfaces de densités dans le NordOuest du Rwanda. pp. 36-46 In: Géographie et Aménagement dans l'Afrique des Grands Lacs. Bordeaux: CRET, Institut de Géographie, Université de Bordeaux III.

Delepierre, G.. 1970. Le bananier. Bulletin Agricole du Rwanda. Octobre 1970. pp. 155-162.

Ferris, R.S.B., Wanda, K., Gaidashova, S.V., Tuyisenge, J., Rucibigango, M., Gatarayiha, C., Mukabazirake, E., Kagiraneza, B. and Ndirigue, J. 2002. Marketing survey of the Banana sub-sector in Rwanda. September 2002, ATDT-CIAT/ISAR/IITA-FOODNET/ CRS, Kigali, Rwanda. 79p. 
Jones, D. R. 1999. Diseases of Banana, Abacá and Enset. CAB International Wallingford, UK.

Kagame, A. 1972. Un Abrégé de l'Ethno-histoire du Rwanda Tome premier. Université Nationale du Rwanda. Collection 'Muntu'. pp. 79.

Karamura, D. and Pickersgill, D. 1999. A classification of clones of East African Highland bananas (Musa) found in Uganda. Plant Genet. Resour. Newsletter 119:1-6.

Karamura, D., Karamura, E.B. and Gold, C.S. 1996. Cultivar distribution in primary banana growing regions of Uganda. Musafrica 9: 35.

Lassoudière, A. 1986. Evaluation et programmation de la recherche bananière au Rwanda. Rapport de mission de A. Lassoudière effectuée su Rwanda du 10 juin au $1^{\mathrm{er}}$ juillet 1986. IRFA, Paris, France.

Lassoudière, A. 1989. Enquête diagnostique sur la Culture bananière en Prefecture de Kibungo. Vol.1, ISAR-IRFA-CIRAD.
Mpyisi, E., Nyarwaya, J. B. and Shyiringiro, E. 2000. Statistiques Agricoles: Production Agricole, Elevage, Superficies et Utilisation des Terres. Année Agricole 2000. MINAGRIFSRP-USAID.

Okech, S. H., Gaidashova, S. V., Gold, C. S., Gatarayiha, C. and Ragama, P. 2002. Banana pests and diseases in Rwanda: A Participatory Rural Appraisal and Diagnostic Survey observations. In: Proceedings of the Integrated Pest Management Symposium, 8 to 12 September 2002, Kampala. Adipala et al.(Eds.), pp. 162-170. NARO/ Makerere University, Kampala, Uganda.

Okech, S. H. O., Gaidashova, S.V., Gold C.S., Nyagahungu, I. and Musumbu, J.T. 2005. The influence of socio-economic and marketing factors on banana production in Rwanda: Results from a Participatory Rural Appraisal. International Journal of Sustainable Development and World Ecology 12:149-160. 